\title{
SERIOUS AND WILFUL MISCONDUCT UNDER THE CALIFORNIA WORKMEN'S COMPENSATION ACT
}

Under the California Workmen's Compensation Act, if the Industrial Accident Commission finds that an employee is injured due to the serious and wilful misconduct of his employer, the worker is entitled to fifty per cent of his normal award as additional compensation. ${ }^{1}$ Conversely, with certain exceptions, the employee, if guilty of serious and wilful misconduct, receives only half of his normal award. ${ }^{2}$ This is one of the few remaining vestiges of the fault concept in the field of workmen's compensation, for the employer is hable for the normal award even though there be no fault on his part and even though the employee be contributorily negligent. ${ }^{3}$

The employer is not permitted to carry insurance to cover the added liability for serious and wilful misconduct. ${ }^{4}$ Furthermore, even though most states give the employee the option to seek redress in a civil action when the injury is due to the employer's wilful misconduct, ${ }^{5}$ California, with one exception, ${ }^{6}$ has provided that the remedy under the compensation act shall be exclusive. ${ }^{7}$ Thus, even though the employer may not insure against the additional award, the amount of his personal liability in the statutory action $^{8}$ is limited rather than left to the whim of a jury.

The primary purpose of this comment is to examine the present status of the law relating to serious and wilful misconduct of the employer ${ }^{2}$ however, situations in which both the employer and the employee are guilty of serious and wilful misconduct will be discussed briefly.

\section{GENERAI BASIS OF IIABILITY}

Serious and wilful misconduct lias been described as a quasi-criminal act which must be more culpable than grossly negligent, but may involve something less than actual intent to harm the employee. ${ }^{10}$ Determination of the required elements necessary to differentiate classes of fault is inher-

${ }^{1}$ CAC. LAB. CODE $\$ 4553$. ("But such increase of award shall in no event exceed . . \$3,700".)

2 CAL. LAB. CODE $\$ 4551$.

3 Campreir, Workmen's Compensation $\$ 19$ (1935); and see Cat. Const. Art. XX, \& 21. Note, however, that if intoxication proximately causes injury, the employee takes nothing. CAL. LAB. CODE $\$ 5705$.

4 CAL. Irs. Code $\$ 11661$. See E. Clemons Horst Co. v. IAC, 184 Cal. 180, 193 Pac. 105 (1920), holding that this no-insurance scheme did not result in a "penalty" but was merely additional "compensation." Note that Cax. INs. CoDE $\$ 11661.5$ prohibits the employer from insuring for the added award allowed to injured, illegally employed minors under CAL. LAB. CODE \& 4557.

5 Labson, Workmen's Comprensatton $\$ 69.10$ (1952).

6 Failure to carry insurance for the normal award subjects the employer to an optional civil action, CAL. LAB. CODE \$3706. However, if the fallure to insure is wilful and the employee chooses to recover under the compensation act, he receives a 10 per cent addition to his normal award. CAL. LAB. CODE $\$ 4554$.

7 CAL. LaB. CODE $\$ \S 3601,5300$.

8 See note 1 supra.

9 For pre-1934 discussion of serious and wilful misconduct see Cominent, 22 CArT. L. Rev. 432 (1934) and Note, 9 CArTr. L. Rev. 352 (1921).

10 Mercer-Fraser Co. v. IAC, 40 Cal.2d 102, 117, 251 P.2d 955, 962 (1933); CaMrpBetr, WORKMEN'S COMTPENSATION $\$ 405$ (1935). 
ently difficult. ${ }^{11}$ Here the courts are faced with the added difficulty that ordinarily the misconduct complained of is not the employer's positive action, but rather his failure to act.

The basic problem, then, is to determine when an employer's ${ }^{12}$ complete inaction, or perhaps ineffective action, is more culpable than grossly negligent. The early leading case of E. Clemons Horst Co. v. Industrial Acc. Comm. ${ }^{13}$ indicated that if the employer knew or should have known that injury was probable, then a failure adequately to guard against the danger would constitute serious and wilful misconduct. ${ }^{14}$ Most of the cases since the Horst decision set a different and expanded standard, namely, that "[S] erious and wilful misconduct is conduct which the employer knew, or should have known, was likely to result in serious ${ }^{15}$ injury or which evinced a reckless disregard for the safety of the employee."16

This added ground for liability, "a reckless disregard for the safety of the employee,"17 seems simply to describe a conscious "I don't care" attitude in relation to employee safety, sufficiently pronounced to supply the moral fault impliedly necessary to support a finding of misconduct more

11 For a scholarly discussion of the general problem of classes of fault see Elliot, Degrees of Negligence, 6 So. CALIF. L. REv. 91 (1933).

12 CAL. LAB. CODE $\$ 4553$ does not require that guilt be necessarily that of the employer, but imputes liability to him, if certain subordinates have the requisite guilt. As to who is an employer see Cal. Shipbuilding Corp. v. IAC, 31 Cal.2d 270, 275, 188 P.2d 27, 31 (1947) (dissenting opinion); Cal. Shipbuilding Corp. v. IAC, 31 Cal.2d 278, 188 P.2d 32 (1947); Bechtel etc. Corp. v. IAC, 25 Cal.2d 171, 153 P.2d 331 (1944); Kaiser Co. v. IAC, 81 Cal. App.2d 818, 185 P:2d 353 (1947).

13184 Cal. 180, 193 Pac. 105 (1920).

14 In the first attempt to define serious and wilful misconduct in California, the court rehed upon Beven, WorkMEN's CoMrPENSATION 394, et seq. (4th ed. 1909), but was forced to analogize, because under the English compensation law serious and wilful misconduct only pertained to the employee. $184 \mathrm{Cal} .180,189,193 \mathrm{Pac} .105,108$ (1920). In stating the requirement that misconduct be both serious and wilful the court said: "Serious misconduct' of an employer must therefore be taken to mean conduct which the employer knew, or ought to have known, if he had turned his mind to the matter, to be conduct likely to jeopardize the safety of his employees.

"... [W]ilful misconduct involves the knowledge of the person that the thing which he is doing is wrong. ... Conceding that knowledge is required, it seems to us that in order to prove the requisite knowledge, it is not necessary for the evidence to show positively that the person was notified of the unsafe condition of the premises, but that the circumstances surrounding the acts of commission or omission are such as "evinced a reckless disregard for the safety of others, and a willingness to inflict the injury complained of." " (Italies added.)

In discussing the evidence, the court states, "It is sufficient if the existence of either his knowledge, or intention, or both, may be inferred. The commission could have decided that Conrad could not lave failed to observe that an operator tending the belt was in perilous proximity to the unguarded shafting. From all the evidence we cannot say that the commission may not have inferred that he must have known of the dangerous conditions of enployment. If he did, as a matter of law he would be guilty of serious and wilful misconduct if he failed to take proper precautions to remove the danger:" (Italics added.) Id. at 191, 193 Pac. at 109.

15 It is not certain what the courts mean by "serious injury." It would seem, however, that the courts are not referring solely to permanent injury or death, but include generally the types of injuries compensable under the act, as distinguished from scratched fingers and the like.

16 Vega Aircraft v. IAC, 27 Cal.2d 529, 533-534, 165 P.2d 665, 66 (1946) (Italics added). See also Parkhurst v. IAC, 20 Cal.2d 826, 129 P.2d 113 (1942) and cases cited therein stating substantially the same rule.

17 This is not a new ground for liability. Substantially the same concept is contained in the Horst definition of "wilful misconduct." See note 14 supra. 
extreme than gross negligence. However, in a few of the recent cases finding liability it appears that the facts showed neither that the employer should have known that danger was probable nor a conscious "I don't care" attitude. ${ }^{18}$ Thus, it is felt that in certain instances the District Court of Appeal has allowed the commission to base its findings of serious and wilful misconduct on something less than gross negligence. However, in the 1953 cases of Mercer-Fraser Co. v. Ind. Acc. Comm. ${ }^{19}$ and Hawaiian Pineapple Co. v. Ind. Acc. Comm.$^{20}$ the California Supreme Court seems to have cut down drastically the "should have known" test as a foundation for the serious and wilful misconduct penalty. A close analysis of these cases is necessary to determine the present standards against which a finding of serious and wilful misconduct is measured.

\section{THE MERCER CASE AND THE HAWAHAN PINEAPPLE CASE}

In the Mercer case, during the construction by the petitioner of some prefabricated buildings, a strong wind arose which caused one of the units to collapse, injuring four employees, two of them fatally. The failure to have adequate bracings was the main cause of the collapse. There was evidence indicating that one of the engineers and several of the supervisory employees had warned petitioner's construction superintendent of the inadequacy of the bracing, but that the superintendent in good faith felt that additional bracing was unnecessary. The commission made a finding of serious and wilful misconduct and proceeded to recite particular findings of what was purported to be serious and wilful misconduct. ${ }^{21}$

18 Johnson v. IAC, 112 Cal. App.2d 363, 246 P.2d 114 (1952) (fall from 9 foot scaffolding because of necessity to stretch in order to plaster inarquee. No safety orders were violated, but one person had mentioned that scaffolding was perhaps in need of guard rails); Chick v. IAC, 107 Cal.App.2d 292, 237 P.2d 8 (1951) (collapse of overloaded platform underhanging high bridge, the dereliction being failure of the foreman to judge the stress and strain of the combined weight of the inen and inaterials on the platform, he having the technical ability to do so). See also, Vega Aircraft Corp. v. IAC, 77 Cal. App.2d 786, 176 P.2d 447 (1947).

10 40 Cal.2d 102, 251 P.2d 955 (1953).

2040 Cal.2d 656, 255 P.2d 431 (1953).

21 40 Cal.2d 102, 121-123, 251 P.2d 955, 965-966 (1953).

" The einployee was injured, in said einployment, by reason of the serious and wilful misconduct of the employer in the manner more particularly as follows: . . . That . . . the employer ... did knowingly and wilfully fail and neglect':

(a) To 'furnish employment, and a place of employment, which was safe for the work. ...'

(b) To 'furnish and use proper, sufficient and adequate safety devices and safeguards; ... so as to prevent the fall or collapse ... during the construction and thereby render sucl ... . place of employment ... safe for the work....'

(c) $\ldots .$.

(d) To 'do those things which a prudent employer would lave done, had it turned its mind to the fact, and which were required to secure, brace, and guy the pre-fabricated parts of a building, to protect the life, limb and safety of the employees. ...'

(e) $\ldots$

(f) To 'use and to exercise that degree of prudence and caution which, under the circumstances, a prudent employer would then and there have used and exercised, had it turned its mind to the fact, in ... directing its employees ... to work upon ... the erection of prefabricated parts of a building, without first insuring . . . proper, adequate, and necessary bracing and guying so as to prevent the collapse of said structure during ... the course of ... said ... construction.'

(g) To 'coinply with the requirement of Labor Code Sections 6400,6401, 6402, and 6403 ... neglecting, and omitting, to provide ... at the place of employment, necessary and adequate bracing and guying ... so as to prevent its fall or collapse during ... said construction." 
The supreme court held that the particular findings indicated that the commission had based its conclusion of serious and wilful misconduct on a theory of negligence and annulled the additional award on that ground. ${ }^{2 a}$ Assuming, without deciding, that the evidence was sufficient to support factual inferences of serious and wilful misconduct on the employer's part, the court held it was clear that the commission had not made such inferences, but had rested its conclusion of serious and wilful misconduct on facts constituting no more than negligence. ${ }^{23}$ And because the commission is the exclusive trier of facts, the court itself would not draw the inferences which the commission might have made, but did not make. ${ }^{24}$

In the lengthy discussion that followed, significant deviations from past judicial expressions appeared. In particular, the court adopted the more exacting standard of "wilful misconduct" imposed in the velicle guest statute cases, ${ }^{25}$ which, seeming to require actual knowededge and belief that danger is probable, leave no room for the "should have known" concept referred to in the earlier workmen's compensation cases. ${ }^{26}$ Antipathy for the "should have known" concept is shown also in the court's suggestion that good faith negates wilfulness. ${ }^{27}$ Thus, the court says: ${ }^{28}$

22 Id. at 124, 251 P.2d at 967 . Notwithstanding CAL. LAB. CODE $\$ 5952$ which provides that "[T] (d) If findings of fact are made, such findings of fact support the order, decision, or award under review," it appears that the recent trend in cases on this point is that, when the findings are insufficient, the court will fill the gap by referring to the record, thus eliminating the necessity of a rehearing on the amended findings. See Taylor v. IAC, 38 Cal. App.2d 75, 100 P.2d 511 (1940) [findings in the words of the statute (CAL. LAB. CoDE § 4553) insufficient]; Dawson v. IAC, 54 Cal. App.2d 594, 129 P.2d 479 (1942) (general statement that employer not guilty of serious and wilful misconduct held sufficient, distinguishing the Taylor case); Vega Aircraft v. IAC, 27 Cal.2d 529, 165 P.2d 665 (1946) (general finding sufficient when it could be made clear by reference to the record , distinguishing Taylor case) ; Lumberman's Mut. Cas. Co. v. IAC, 29 Cal.2d 492, 175 P.2d 823 (1946) ("A finding of ultimate facts in the words of the statute is sufficient," disapproving Taylor case). But cf. Cal. Shipbuilding Corp. v. IAC, 31 Cal.2d 278, 188 P.2d 32 (1947) (finding insufficient; too hard to search the record). Query: Would the 1953 amendment to CAL. LAB. CODE $\$ 5952$, "Nothing in this section shall permit the court to hold a trial de novo, to take evidence, or to exercise its independent judgment on the evidence," induce a court to look to the findings only?

23 Three of the findings stated in substance that the employer had failed to do those things a "prudent employer" would have done "had it turued its mind to the fact," which failure was only negligence. See note 21 supra. The court also stated that the commission must find "an act or omission to which the employer has 'turned his mind," thus adding weight to the apparent elimination of the "should have known" concept. 40 Cal.2d 102, 125, 251 P.2d 955, 967 (1953).

24 Id. at 120,251 P.2d at 964 .

2540 Cal.2d 102, 116-118, 251 P.2d 955, 962-963 (1953).

26 CAL. Ver. Code $\$ 403$ and e.g., Cope v. Davison, 30 Cal.2d 193, 180 P.2d 873 (1947). See also Note, 22 CaLIF. L. REv. 119 (1933).

27 Id. at $120-121,251$ P.2d at $964-965 ; “ . .$. [T] $]$ he very fact that he was worried would seem to negative, rather than affirm, either an intent to harm or a wanton, positive and absolute disregard of possible harm."

28 Id. at 118, 251 P.2d at 963. Compare the following guest statute cases in which the court held the evidence insufficient for a finding of "wilful misconduct": Meek v. Fowler, 3 Cal.2d 420, 45 P.2d 194 (1935) (racing for intersection); Howard v. Howard, 132 Cal. App. 124, 22 P.2d 279 (1933) (driving too fast on wet road); with these employment cases in which the additional award was allowed: Cal. Shipbuilding Corp. v. IAC, 27 Cal.2d 536, 165 P.2d 669 (1946) (failure to have guard rails); Bethlehem Steel Co. v. IAC, 23 Cal.2d 659, 145 P.2d 583 
Manifestly, "serious and wilful misconduct" cannot be established by showing acts any less culpable, any less deliberate, or any less knowing or intentional, than is required to prove wilful misconduct.

The apparent rule at which the court finally arrives is that serious and wilful misconduct is an act or failure to act ${ }^{29}$

... deliberately done for the express purpose of injuring another, or intentionally performed either with actual knowledge that serious injury is a probable result, or with a positive, active, wanton, reckless and absolute disregard of its possible damaging consequences....

Applying this rule, the court then held that the particular findings of the commission did not show that the petitioner had the requisite knowledge that he was placing his employees in a position of danger to justify holding him guilty of serious and wilful misconduct. ${ }^{30}$

To be deduced from the Mercer decision is the following general attitude: If the evidence indicates that the employer, being experienced in his (1944) (failure to secure load) ; Ethel D. Co.v. IAC, 219 Cal. 699, 28 P.2d 919 (1934) (failure to provide secure handhold for ladder); Johnson v. IAC, 112 Cal. App.2d 363, 246 P.2d 114 (1952) (failure to have guard rails); Chick v. IAC, 107 Cal. App.2d 292, 237 P.2d 8 (1951) (allowing platform to become overloaded). All but the last two cases involved violation of safety orders.

$2940 \mathrm{Cal} .2 \mathrm{~d} 102,120,251$ P.2d 955, 964 (1953) (italics added). But see discussion at note 36 infra. It is perhaps pertinent to note that, in arriving at this rule, the court drew on none of the definitions evolved in the past compensation cases on the point. However, it is felt that many of the earlier cases are still good law, smce the facts in each gave sufficient warning of the danger to allow imputation of the knowledge of danger now required. In some cases there had been similar past accidents. Vega Aircraft v. IAC, 27 Cal.2d 529, 165 P.2d 665 (1946); Hatheway v. IAC, 13 Cal.2d 337, 90 P.2d 68 (1939); Johannson v. IAC, 113 Cal.App. 162, 298 Pac. 99 (1931) ; Clarke v. IAC, 87 Cal. App. 766, 262 Pac. 471 (1927). In some there had been warnings by officials. Parkhurst v. IAC, 20 Cal.2d 826, 129 P.2d 113 (1942) (health authorities and employees); Blue Diamond Plaster Co. v. IAC, 188 Cal. 403, 205 Pac. 678 (1922) (commission inspectors); Cook v. Madison, 5 CCC 153 (1940) (employer's insurance carrier); Hughes Paint Co. v. IAC, 5 CCC 207 (1940) (fire department). But of. Evans v. Union Oil Co., 11 IAC 115 (1924) (recommendation of safety department of Industrial Accident Commission not enough in itself). In others there had been warnings by the employees, Gordon v. IAC, 199 Cal. 420, 249 Pac. 849 (1929); Vega Aircraft v. IAC, 77 Cal. App.2d 786, 176 P.2d 947 (1947); General Petroleum Corp. v. IAC, 90 Cal. App. 101, 265 Pac. 508 (1928); Cal. Shipbuilding Corp. v. IAC, 7 CCC 300 (1942).

See the following cases in which the circumstances were not sufficient to notify the employer of the possibility of danger: Cal. Shipbuilding Corp. v. IAC, 31 Cal.2d 278, 188 P.2d 32 (1947); Cadotte v. IAC, 86 Cal. App.2d 754, 194 P.2d 563 (1948); Central Calif. Ice Co. v. IAC, 66 Cal. App.2d 339, 152 P.2d 33 (1944); Dawson v. IAC, 54 Cal. App.2d 594, 129 P.2d 479 (1942); Helmick v. IAC, 46 Cal.App.2d 651, 116 P.2d 658 (1941); Atkinson v. IAC, 38 Cal.App.2d 336, 101 P.2d 156 (1940); City of Long Beach v. IAC, 138 Cal.App. 53, 31 P.2d 445 (1934); Green v. IAC, 130 Cal. App. 337, 19 P.2d 1029 (1933).

$3040 \mathrm{Cal} .2 \mathrm{~d} 102,125,251$ P.2d 955,967 (1953). The Mercer court is in reality saying that a finding of "serious misconduct," as defined in the Horst case, note 14 supra, is not sufficient. See the findings in Vega Aircraft v. IAC, 77 Cal.App.2d 786, 176 P.2d 447 (1947), which were allowed to support the additional award even though quite similar to those in the Mercer case. See also Hawaiian Pineapple Co. v. IAC, 40 Cal.2d 656, 663, 255 P.2d 431, 435 (1953), which disapprovcs like findings, stating, "The standard requires an act or omission to which the $\mathrm{cm}$ ployer has 'put his mind," " and, "A 'reckless disregard' of the safety of the employees is not sufficient in itself unless the evidence shows that the disregard was more culpable than a careless or even a grossly careless omission or act. It must be an affirmative and knowing disregard of the consequences." 
field, honestly ${ }^{31}$ concludes that no further safety precautions need be taken, then the fact that his conclusion is not justified by the actual situation is immaterial. However, if it could be inferred that the employer was weighing the cost of adequate safety measures against the probability of danger to his employees, he would seem to be acting in bad faith rather than reaching an "honest conclusion."

The cases of Sutter Butte Canal Co. v. Ind. Acc. Comm. ${ }^{32}$ and Hawaiian Pineapple Co. v. Ind. Acc. Comm..$^{33}$ follow the standard of the Mercer case in ruling on the evidence. The Sutter case, decided the same day as Mercer, held that the evidence was insufficient as a matter of law to sustain a misconduct finding. There the evidence seemed to indicate that the employer's mind had never been truly directed to the circumstances of danger, nor was there substantial reason to believe that serious injury was probable.

In the Hawaiian Pineapple case, however, the employer admittedly knew that the circumstances were dangerous, and the propriety of the misconduct findings involved the steps taken to guard against danger. A fork lift driver was struck by a switch engine while negligently crossing some railroad tracks which lay between a warehouse and the company's main plant. The accident occurred during the "off season." During the busy season a watchman had been employed to warn against oncoming trains, but in the "off season" the only precaution was warming signs and instructions to the lift drivers to stop at the crossing. The company's lift drivers daily made many crossings, and three days before the injury another driver, nearly struck by a train, had complained to the employer's representative. As a result the employer had installed a mirror device by means of which the employees could see about twenty feet along the tracks.

Following the standard discussed in the Mercer case, the court annulled the award on the ground that, although the mirror device had proved ineffectual, there was no substantial evidence in the record indicating that the employer had knowledge or a belief that this remedy was inadequate. The language of the court indicated that if the employer had taken no action after being informed of the near accident, he would have been guilty of serious and wilful misconduct. ${ }^{34}$ The court further stated, " $[\mathrm{N}]$ or does the

31 In Sutter Butte Canal Co. v. IAC, 40 Cal.2d 139, 251 P.2d 975 (1953), the employer had complied with substantially all recommendations made by the commission, and in Hawaiian Pineapple Co. v. IAC, 40 Cal.2d 656, 660, 255 P.2d 431, 433 (1953), the court seemed impressed with the company's "energetic safety program." Note also, that in both the Mercer case, 40 Cal.2d 102, 123, 251 P.2d 955, 966 (1953), and the Hawaiian Pineapple case, supra at 661, 255 P.2d at 434, the commission referee found the employer not guilty of serious and wilful misconduct.

3240 Cal.2d 139, 251 P.2d 975 (1953). Same case below, 241 P.2d 1008 (Cal. App. 1952).

3340 Cal.2d 656, 255 P.2d 431 (1953).

$34 I d$. at $664-665,255$ P.2d at 436. In holding that the employer bad no "actual knowledge" of the probable consequences of its failure to provide more adequate safety devices or a safer place to work, the court intimated that if the employer had taken no steps at all to remove the hazard after notice of the recent injury, then "at least constructive knowledge could bave been imputed to the employer ... that such accident might occur again." The court seems to approve of the rule that there must be "actual knowledge." Constructive knowledge would seem to mean knowledge that is imputed to the reasonable and prudent man under given facts, CAr. 
record reveal that there was any reason for it to believe that the circumstances which nearly caused a first accident continued to exist." ${ }^{35}$

This last quoted statement suggests that, while the court professed to follow the language of the Mercer case, it may nevertheless have retreated somewhat in the Hawaiian Pineapple case from the complete rejection of the "should have known" test of serious and wilful misconduct suggested in Mercer..$^{36}$ Given a case with evidence that the employer had his mind directed to the fact of danger, it would seem eminently proper that the commission might find that the employer knew or should have known that injury was likely.$^{37}$ Otherwise the courts would be placing a premium on ignorance of matters that are defimitely the employer's responsibility.

In concluding its opinion, the court in the Harraiian Pineapple case, as it had done in Mercer, stressed the fact that no violation of either an express statute or a safety order of the commission was involved and that, "The rules laid down im such cases ... as to what constitutes 'serious and wilful misconduct' therefore have no application." 38

\section{SAFETY ORDERS AND SAFETY STATUTES}

Examination of the latter rules, which the court regards as standing on a different foundation, reveals that the courts have stated that violation of

CIv. CODE $\S 19$, and it is suggested that the court is either backtracking from its requirement of actual knowledge or that it did not intend the statutory meaning to be given to the term due to the strong enunciation in the Mercer case that the standard is not that of the reasonable man.

3540 Cal.2d 656, 665, 255 P.2d 431, 436 (1953).

$36 \mathrm{~A}$ term we may see more of is "actual knowledge, or that which in law is deemed to be the equivalent of actual knowledge." This was one of the many definitions quoted in Mercer, 40 Cal.2d 102, 117, 251 P.2d 955, 962 (1953). In the Hawaizan Pineapple decision the court was more selective $\mathrm{m}$ its choice of quotes and, though not using this term in its final discussion of the evidence, cited it with apparent approval. 40 Cal.2d 656, 662, 255 P.2d 431, 434 (1953).

Porter v. Hofman, 12 Cal.2d 445, 448, 85 P.2d 447, 448-449 (1938), the guest statute case from which the above quotation was taken, holds that, "Before liability arises there must be shown actual knowledge, or its equivalent, on the part of the defendant of the peril to be apprehended ... . There is no circumstance in the record disclosing either express or implied knowledge . . . that possible injury . . . would follow . . . " (Italics added). In a more recent guest case, Cope v. Davison, 30 Cal.2d 193, 180 P.2d 873 (1947), the appellant's main contention was that the trial court did not sufficiently impress upon the jury that no specific intent to do harm was necessary, but that it was enough that there be knowledge, express or implied. The court approved the instructions under attack, but emphasized that the jury can decide from all the facts and circumstances whether the defendant had actual knowledge of probable danger.

Therefore, in the Hawaizian Pineapple case, the court's use of the terms "reason to believe," "constructive knowledge" (see note 34 supra), and "equivalent of actual knowledge" would seem to indicate that the "should have known" language is not completely dead, but is perhaps revitalized under a different name. However, because the elimination of the "should have known" language must have some significance, it is suggested that it is sufficient if the commission, from all the facts and circumstances, can find that the employer "must have known" that danger was probable. Substantially the same thought is expressed in the discussion of the evidence in the Horst case. See note 13 supra.

37 Compare Norton v. Puter, 139 Cal.App. 253, 32 P.2d 172 (1934) (guest statute case in which the fact that the driver had been warned and had skidded previously on the same curve was held to be enough to snpport liability) with Howard v. Howard, 132 Cal. App. 124, 22 P.2d 279 (1933) (guest statute case reversed on appeal: only some evidence of warning).

3840 Cal.2d 656, 665, 255 P.2d 431, 436 (1953); Mercer-Fraser Co. v. IAC, 40 Cal.2d 102, 118, 251 P.2d 955, 963 (1953). 
a safety order is not serious and wilful misconduct per $s e,^{39}$ and that each case involving violation of a safety order must rest on its own particular facts. ${ }^{40}$ It is sigmificant, however, that in all of the cases since 1932 in which the court has found a violation of a safety order, with one possible exception, ${ }^{41}$ the additional award has been allowed. ${ }^{42}$

Safety orders are made expressly for the safety and welfare of the employees. They must be based on facts solicited at a hearing showing that they are essential to the protection of life or safety and apparently must be served upon the employer to be effective. ${ }^{43}$ The rule of the safety order violation cases seems to be that in knowingly violating a safety order, the employer knew or should have known that injury was likely, since the promulgation of the order was based on the likelihood that injury would occur. .4 $^{4}$

39 This is contrary to a suggestion made by the author of a comment in this review. See 22 CALTr. L. REv. 432, 437 (1934).

10 In Ethel D. Co. v. IAC, 219 Cal. 699, 704, 28 P.2d 919, 921 (1934), the court stated, "... [T] he mere failure of an employer to comply literally with the requirements of a safety order of the Industrial Accident Commission does not in itself justify a finding that the employer is guilty of serious and wilful misconduct."

41 Folsom v. IAC, 3 Cal.App.2d 282, 38 P.2d 786 (1934).

42 Cal. Shipbuilding Corp. v. IAC, 31 Cal.2d 270, 188 P.2d 27 (1947); Cal. Shipbuilding Corp. v. IAC, 27 Cal.2d 536, 165 P.2d 669 (1946); Bethlehem Steel Co. v. IAC, 23 Cal.2d 659, 145 P.2d 583 (1944); Ethel D. Co. v. IAC, 219 Cal. 699, 28 P.2d 919 (1934); Cal. Shipbuilding Corp. v. IAC, 64 Cal.App.2d 622, 149 P.2d 432 (1943).

The following cases hinged on the violation of a safety order. In each case the main reason for annulling the increased award was that the court felt that the safety order was not in fact violated. Simmons Co. v. IAC, 70 Cal.App.2d 664, 161 P.2d 702 (1945); Barnes Construction Co. v. IAC, 65 Cal.App.2d 249, 150 P.2d 527 (1944); Chain v. IAC, 135 Cal.App. 260, 26 P.2d 856 (1933). See also Bechtel Etc. Co. v. IAC, 25 Cal.2d 171, 153 P.2d 331 (1944), in which the court held that there was a violation, but not by the employer or a managing officer thereof.

43 CAT. LAB. CoDE $\$ \$ 6500,6502,6503$. As to the necessity of service see Schmidt v. Pursell, 47 Cal_App. 440, 190 Pac. 846 (1920); Helme v. Great Western Milling Co., 43 Cal.App 416, 185 Pac. 510 (1919); Hopkinson v. Kier, 12 IAC 92 (1925); Boesche v. Davison, 8 IAC 128 (1921); Burke v. Chandler Shipbuilding Co., 5 IAC 237 (1918); CAMrpbel, WorkMren's CoMrpensation $\$ \S 414,417,1763$ (1935). See also Hoffman v. Dept. of Indust. Relations, 209 Cal. 383, 387, 287 Pac. 974, 976-977 (1930).

44 In Bethlehem Steel Co. v. IAC, 23 Cal.2d 659, 663, 145 P.2d 583, 585 (1944), the court cites with approval a statement in Parkhurst v. IAC, 20 Cal.2d 826, 830, 129 P.2d 113, 116 (1942), a safety statute case, in which it is said that a knowing violation of a safety law should be "serious misconduct." See note 50 infra, for discussion of the import of this statement.

In the hight of the present court's emphasis that good faith is incompatible with wilfulness, it is conceivable that an employer could knowingly violate a safety order and yet not be guilty of serious and wilful misconduct. In Pacific Employer's Ins. Co. v. IAC, 209 CaI. 412, 288 Pac. 66 (1930), the employer did violate a safety order of the commission which required a guard for a certain saw, but had the guard on order and took such care in insuring safe operation in the interim that the dissenting judge felt that there was no evidence whatsoever of serious and wilful inisconduct. See also Morton v. Thatcher, 10 IAC 51 (1923) (commission held that failure to read and comply with safety orders was due to good faith, excusable neglect). But of. Bethlehem Steel Co.v. IAC, supra at 665,145 P.2d at 586, (violation of safety order: "The mere fact that the employer did not believe the condition was dangerous does not relieve him from liability"). Accord: Blue Diamond Plaster Co. v. IAC, 188 Cal. 403, 409, 205 Pac. 678, 681 (1922). 
Specific $^{45}$ safety statutes are to be distinguished from safety orders. ${ }^{40}$ Since safety statutes are not served upon the employer, actual knowledge of the safety requirement is not always present in cases of their violation. Even though the employer is charged with knowledge of the law, ${ }^{47}$ it has been said that not every violation of a statute is serious and wilful misconduct. ${ }^{48}$ Thus, something more than mere breach of statutory law is necessary to find the employer guilty of serious and wilful misconduct.

In Parkhurst v. Ind. Acc. Comm., ${ }^{42}$ the employer not only violated a community drinking water statute, but heard conplaints by his employees and was told by the health authorities to desist from violating the statute. These additional facts should have been enough to charge the employer with serious and wilful misconduct. The court, however, relied primarily upon the violation of the statute, mdicating that where a statute specially enacted for the safety of the employee is violated the employer will in most instances be charged with knowledge that danger is likely. ${ }^{50}$ Yet the court

45 CAL. LAB. CODE $\$ \$ 6400-6403$ provide generally that the employer must furnish safe working conditions and all necessary safety devices. These are general requirements and should be distinguished from specific safety statutes, e.g., CAL. LAB. CODE $\$ 7325$ et seq. requiring certain safety devices for window cleaners.

In Sutter Butte Canal Co. v. IAC, 40 Cal.2d 139, 144, 251 P.2d 975, 979 (1953), Justice Carter in a dissenting opinion thought that Sections 6400-6403 were violated, but the majority, id. at 143, 251 P.2d at 978 , took the view that it cannot be decided that a person is guilty of serious and wilful misconduct merely because the place of employment has given birth to an accident. In the Mercer case, 40 Cal.2d 102, 126, 251 P.2d 955, 968 (1953), the court, in discussing the above sections of the Labor Code, states that the employer is not to be burdened with the duty of an insurer. See also, Helme v. Great Western Milling Co., 43 Cal.App. 416, 424, 185 Pac. 510, 513 (1919), in which the court states that the requirements of the Labor Code are only general, and that "the act does not require defendant to provide or maintain a place of employment that does not involve any element of danger whatever." However, Johnson v. IAC, 112 Cal.App.2d 363, 246 P.2d 114 (1952), and Chick v. IAC, 107 Cal.App.2d 292, 237 P.2d 8 (1951), seem to predicate their decisions on an apparent violation of the above-mentioned code sections.

40 Violation of either safety orders or safety statutes is usually a misdemeanor. See, e.g., CAI. LAB. CODE $\$ \S 6315,6414,6511,7156$.

47 Ignorance of a safety law is no excuse. See Hoffman v. Dept. of Industrial Relations, 209 Cal. 383, 389, 287 Pac. 974, 977 (1930) ; CaMppele, Workmen's CoMpensation § 1762 (1935).

48 Parkhurst v. IAC, 20 Cal.2d 826, 129 P.2d 113 (1942); Hoffman v. Dept. of Industrial Relations, supra note 47. Cf. Meek v. Fowler, 3 Cal.2d 420, 45 P.2d 194 (1935) (guest statute case).

4920 Cal.2d 826, 129 P.2d 113 (1942).

50 Id. at 830,129 P.2d at 116: "Where there is a debiberate breach of the law ... which is framed in the interests of the workingman, it will be held that such a breach . . . amounts to serious misconduct." (Italics added.)

Ancient history plagues us. "Serious misconduct" as per the Horst case, 184 Cal. 180, 193 Pac. 105 (1920), seems to test the degree of danger, i.e., is serious injury likely? However, the quotation above is taken from Maryland Fidehty etc. v. IAC, 171 Cal. 728, 730-731, 154 Pac. 834, 835 (1916), decided prior to the Horst case and involving only "wilful misconduct" of an employee.

The Horst definition was evolved from Beven, Workaren's CoMrpensation 394 et seq. (4th ed. 1909), whereas the Fidelity court relied on WIIIIS, Workanen's CoMrPENSATION 52 et seq. (14th ed. 1914). Both texts cover the English Workmen's Compensation Act of 1906. Serious and wilful misconduct is an offense only of the employec under that act, and both authors treat "serious misconduct" separately. The general tenor of both texts is that "serious 
does not hold that violation of a statute is serious and wilful misconduct per se. Thus, apparently, a knowing violation of a specific safety statute would usually constitute serious and wilful misconduct.

Omission of the cases involving safety statutes from the discussion in the Mercer and Hawaiian Pineapple cases perhaps indicates that they are approved. ${ }^{51}$ However, where there is no knowledge of the statute, it would seem that the present court will require that there be either actual knowledge of the fact of danger and a resulting failure to attempt in good faith to remove the danger, or a reckless disregard of employee safety. ${ }^{52}$

\section{AFFIRMATIVE ACTS}

The discussion above is directed primarily to situations in which the employer was alleged to have failed to guard against a known danger. But, suppose a high dam has a mechamical sluice gate and, after ordering the employee to remove the flash boards from the gate, that the employer opens the gate and the resulting stream of water washes the employee over the dam. Here is active misconduct, rather than inaction, and it seems clear that the employer has knowledge of the situation of danger. Assuming that injury was highly probable under such circumstances, even though it be assumed that the employer did not intend to harm his employee and that he merely "forgot," it has been held under similar circumstances that forgetfulness is no excuse. ${ }^{53}$

Since in such cases the employer creates the situation of danger, rather than fails to guard agamst it, there can be no problem of knowledge, and the Mercer case indicates that the law of the guest statute decisions may be applicable in determining whether the conduct exceeds in culpability that which the law has delineated as gross negligence.

misconduct" tests the degree of danger appreciated by the reasonable employee, but that "wilful misconduct" involves deliberation and knowledge.

Therefore, even though it possibly could be argued that the quotation from the Fidelity case indicates an intent by the court in Parkhurst to hold that violation of a statute is serious and wilful misconduct (because of the indication in Fidelity that the quoted conduct results in "wilful misconduct,") it is felt that the present court has not so held because: (1) historically, "serious misconduct" is not serious and wilful misconduct, and (2) if the court had desired so to hold, it would have used clearer language than the obscure term "serious misconduct."

However, in the Parkhurst case, 20 Cal.2d 826, 830, 129 P.2d 113, 115 (1942), the court states, "The test under these cases is whether the employer knowingly or wilfully committed an act that he knew or should have known was likely to cause harm to his employee." (Italics added.) If the act is a knowing violation of the statute, then the rule seems completely valid. But if the act is the mere physical act of violation, then this rule is thought to be unacceptable, especially if the court continues to accept the rule that there inust be an intent to do a wrongful act, not the mere doing thereof. See note 52 infra.

51 See note 38 supra.

52 Mercer-Fraser Co. v. IAC, 40 Cal.2d 102, 118, 251 P.2d 955, 963 (1953), impliedly accepts the rule that wilfulness requires the intent to do a wrongful act, not the mere doing thereof. It follows that an unknowing violation of a statute lacks that intent.

63 Kaiser Co. v. IAC, 81 Cal.App.2d 818, 185 P.2d 353 (1947) (operated rock crusher while employee still inside). See also Coogan Productions v. IAC, 21 Cal.App.2d 255, 68 P.2d 750 (1937) (reckless driving); Anderson, Clayton and Co. v. IAC, 19 CCC 24 (1954) (writ to review finding of serious and wilful misconduct demed). 
Section 4551 of the Labor Code provides that the normal award of the employee shall be reduced by one-half if he is found guilty of serious and wilful misconduct except when injury results in death, where there is permanent disability of 70 per cent or more, where the employee is under the age of 16 , or when the injury was a result of a violation of safety laws or orders by the employer. The author of a comment in this review, ${ }^{\text {t4 }}$ being of the opinion that this provision did not in fact promote greater safety for employees, thought that it had no valid purpose. The code section has not been repealed, but it does appear that the commission has rarely found an eniployee guilty of serious and wilful misconduct. ${ }^{55}$

Due to the scarcity of appellate decisions on the issue of employee misconduct since the publication of the aforementioned comment, nothing has been added to the early analysis of the elements necessary to support a finding of employee serious and wilful misconduct; that analysis will therefore not be repeated here. ${ }^{56}$ However, a difficult question arises when both the employer and the employee are found guilty of serious and wilful misconduct. Neither the statutes nor the case law have given a definitive answer as to the proper amount of recovery in such a situation.

Assuming that both the employer and the employee are found guilty of serious and wilful misconduct, but the situation comes within the exceptions of Section 4551, it seems that the proper, if not the present, rule is that the employee's serious and wilful misconduct is not a defense to an action for additional compensation under Section 4553. This is the Commission's rule, ${ }^{57}$ a recent appellate decision has "almost" held to that effect, ${ }^{58}$ and, because the appellate courts have termed the "exceptions" a complete $d e$ fense when no employer misconduct is mvolved, ${ }^{50}$ it is felt that the allow-

54 Comment, 22 CALrF. L. Rev. 432 (1934).

55 Since the publication of the comment cited in note 54 there have been no appellate decisions on point. Only five published decisions of the commission have held the employee guilty of serious and wilful misconduct: Shivell v. IAC, 17 CCC I (1952); Bethlehem Steel Co. v. IAC, 11 CCC 83 (1946); Cook v. Madison, 5 CCC 153 (1940); Graf v. Lukens, 4 CCC 146 (1939); Smith v. Broadway Productions, 20 IAC 6 (1934).

56 However, we can speculate as to the present status of the law, because the courts have stated that the same standard shonld be apphed to the employee as is apphed to the employer. Hawaiiau Pineapple Co. v. IAC, 40 Cal.2d 656, 664, 255 P.2d 431, 435 (1953); Mercer-Fraser Co. v. IAC, 40 Cal.2d 102, 109, 251 P.2d 955, 957 (1953). See also Auto-Lite Battery Co. Etc. v. IAC, 77 Cal.App.2d 629, 176 P.2d 62 (1947), in which the commission had found the employee guilty of serious and wilful misconduct, but the only question on appeal was whether such misconduct took the einployee out of the scope of employment. Thus, as the general requirements of employer serious and wilful misconduct change, so should the requirements in relation to the einployee.

57 Cook v. Madison, 5 CCC 153 (1940) (violation of safety order).

68 Bethlehem Steel Co. v. IAC, 23 Cal.2d 659, 154 P.2d 583 (1944). The court, while finding the employer guilty of serious and wilful misconduct in violating a safety order, assumed, without deciding, that the employee was also guilty of serious and wilful misconduct and said that such misconduct was no defense under Section 4551 when the employer has violated a safety order of the commission. However, the court went on to say that the employee was not guilty of serious and wilful misconduct.

50 Western Pac. Ry. v. IAC, 193 Cal. 413, 224 Pac. 754 (1924) (injury resulted in death). 
ance of the additional award in such a situation is an inescapable conclusion. ${ }^{60}$

A much more difficult problem arises when both parties are found guilty of serious and wilful misconduct but the exceptions of Section 4551 do not apply. There are three possible results: (1) to allow the complete additional award; (2) to increase the normal award by 50 per cent and then to reduce the resulting amount by 50 per cent, thus allowing only 75 per cent of the normal award to go to the employee; or (3) to treat the serious and wilful misconduct of one party as canceling that of the other, thus leaving the normal award intact.

There seems to be no basis in law or in equity for allowing the additional award notwithstanding the misconduct of the employee, ${ }^{61}$ although there is some language in one case which possibly could be read to intend such a result. ${ }^{62}$ The second alternative, 75 per cent of the normal award, is a little more plausible because Section 4551 speaks in terms of reducing the award "otherwise recoverable." Thus, if no employee serious and wilful misconduct is shown, under Section 4553 the award "otherwise recoverable" would be 150 per cent of the normal award. A 50 per cent reduction thereof amounts to 75 per cent of the normal award. ${ }^{63}$ However, it seems more logical to say that "otherwise recoverable" in Sections 4551 and 4553 means the normal award and, the base for applying the percentages being constant, that the increases and decreases cancel themselves out, leaving the normal award intact.

This result, but not necessarily the reasoming, was followed in a commission decision. ${ }^{64}$ Even though it is thought that this is the only reasonable

60 Where an employer's managing representative has been injured due to the alleged serious and wilful misconduct of the employer, but the employee, being the employer's alter ego and having the duty to prevent the misconduct complained of, fails in that duty, the rule seems to be that he cannot increase the normal award by his own misconduct. Guy F. Atkinson Co. v. IAC, 38 Cal.App.2d 366, 110 P.2d 156 (1940); Folsom v. IAC, 3 Cal.App.2d 282, 38 P.2d 786 (1934) semble; White v. IAC, 9 CCC 170 (1944). These cases were distinguished in the Bethlehen case. See note 58. It would seem, however, that they are a good indication that the courts would not allow the additional award where the exceptions of CAL. LAB. CoDE $\S 4551$ do not apply.

61 Especially in light of the specific exceptions of CAL. LAB. CODE $\S 4551$. See also note 60 supre.

62 In Bethlehem Steel Co. v. IAC, 23 Cal.2d 659, 665, 145 P.2d 583, 587 (1944), Justice Carter stated by way of dictum, "It also must be true that [employee serious and wilful misconduct] is not a defense when the claim is for additional compensation by reason of serious and wilful misconduct of the employer." However, when read in context, it would seem that this statement only means that because employee misconduct is no defense in the normal situation when the exceptions of Section 4551 apply, such misconduct should not be a defense when the application is for the additional award and the exceptions apply.

It also could be argued that when an employer is guilty of serious and wilful misconduct, $a$ priori he violates Sections $6400-6403$ of the Labor Code (see note 45 supra) and because a statute has been violated, the exceptions of Section 4551 apply.

03 The same result is reached if the computation is started with the reduced award under Section 4551 and then increased under Section 4553 . However, this would not be the liberal interpretation of the statute for the henefit of the imjured person, required by CAI. LAB. CODE $\$ 3202$.

84 Walker v. Arctic Machine Co. Etc., 19 IAC 48 (1933). 
conclusion that can be drawn, the appellate courts have never passed on the question and it therefore remains open. ${ }^{65}$

\section{CONCLUSION}

In the Mercer case Justice Carter states that the obviously stricter interpretation by the majority "is the age old reactionary concept of property rights above human welfare." "The Workmen's Compensation Act requires that the provisions of the code shall be liberally construed by the courts with the purpose of extending their benefits for the protection of the persons injured in the course of employment. ${ }^{67}$ Assuming that the serious and wilful misconduct sanctions have a salutary effect in preventing accidents, it is arguable that they should be liberally applied to further that objective. ${ }^{68}$ In the opinion of this writer, however, these added awards are in the nature of a bonus to the employee. Once the employee receives his normal award it would seem that there is no good reason for giving him any advantage in litigating for the additional award. The serious and wilful misconduct provision, being in the nature of a criminal penalty against the employer, should be strictly construed. ${ }^{69}$

$$
\text { Herbert P. Moore, Jr.* }
$$

65 Assuming, where both employer and employee have been found guilty of serious and wilful misconduct, that the employee should receive an award in the normal amount, the question arises, as between the insurer and the employer, who should pay. On the ground that the insurer would he liable for the normal award in the absence of serious and wilful misconduct of the employee, and accepting the theory that serious and wilful misconduct of one party cancels that of the other, it could be argued that the insurer should pay the entire award in the normal amount. On the other hand it would seem not unreasonable to hold that the insurer and the employer each should pay half the normal award, since that is what the insurer would be required to pay in case of the employee's serious and wilful misconduct and is also the amount the employer, guilty of serious and wilful misconduct, must pay.

6640 Cal.2d 102, 132, 251 P.2d 955, 971 (1953). In his dissent in the Harvaiian Pineapple case, 40 Cal.2d 656, 665, 255 P.2d 431, 436 (1953), Justice Carter said, "The lethal blow has been struck and section 4553 ... has been nullified and stricken from the statute hooks by judicial interpretation."

${ }^{87}$ CaL. LAB. CODE $\$ 3202$.

68 Comment, 22 CAxIr. L. REv. 432 (1934) and see Justice Carter's dissent in the Mercer case, 40 Cal.2d 102, 132, 251 P.2d 955, 971 (1953).

60 The majority in the Mercer case, 40 Cal.2d 102, 108, 251 P.2d 955, 957 (1953), argues that the increased benefits are "actually in the nature of a penalty," whereas Justice Carter states, "In the first place the additional award is not a penalty." Id. at 138, 251 P.2d at 975.

CAMMPBELr, WORKMEN's COMTPENSATION $\$ 423$ (1935), agrees that it is a penalty and that the section should be strictly construed. Cf. McPheeters v. Board of Medical Examiners, 103 Cal.App. 297, 299, 284 Pac. 938, 939 (1930) ("the statute [to revoke doctor's license] is in its nature penal, and such laws are to he strictly construed in favor of the accused").

* Member, Third Year Class. 